\title{
ARCHAEOLOGICAL TRACES OF RURAL COIN COUNTERFEITING IN TOLNA COUNTY IN THE 16TH-17TH CENTURIES
}

MátÉ VARgA ${ }^{1}$ - András K. NÉmeth ${ }^{2}$

Hungarian Archaeology Vol. 10 (2021), Issue 1, pp. 63-70. https://doi.org/10.36338/ha.2021.1.6

"Hidden in dark forests, shifty characters with shady pasts were producing caps full of coins or Polish groschen from base metal in peasant cottages" (KомÁROMY 1893, 648). It is as if András Komáromy in his 1893 story for the journal Századok was describing the archaeological finds from Tolna County we will present below. The scene he portrays was of the difficult times following the Battle of Mohács, when even poor people tried their hand at the forbidden activity of counterfeiting. We can learn of the efforts of noblemen at counterfeiting from the work of Komáromy through the confession of a man (master Nicholas) accused of this activity.

One of the most interesting parts of the science of numismatics is counterfeiting, because it is only a slight exaggeration that there have been fakes ever since the birth of money. Despite the distinctive nature of the topic, little is known of it even today. Knowledge is particularly scanty about so-called rural counterfeiting workshops, with few written sources - in contrast to those on counterfeiting by noblemen. In our paper we would like to provide some useful archaeological data primarily through surveys with metal detectors and field walks on a relatively small but intensively studied topic of the Ottoman Period.

Keywords: coin counterfeiting, numismatics, Early Modern Period, Ottoman Turkish Period, Tolna County, Southern Transdanubia

\section{HISTORICAL OVERVIEW}

Counterfeiting had been present in the Kingdom of Hungary since the Árpád Period, although it is not really mentioned in written sources. Laws do not dwell upon it specifically either, but it was certainly considered treachery or lese-majesty in common law (KAHLER 1977-1978, 57-59). The counterfeiting of coins rears its head at different scales in every century, but it became particularly conspicuous during the rule of King Sigismund of Luxemburg (1387-1437), when there is evidence of counterfeiting activities not only on a small, personal basis, but of criminals working under the protection of particular landlords. Counterfeiting even took place at the mints, or the coin dies from the mints were used illegally elsewhere (KAHLER 1981-1982, 79-80). After the Battle of Mohács in 1526, alongside the legal coinage of the two new kings - Ferdinand I (1526-1564) and John Szapolyai (1526-1540) - several aristocrats and noblemen were minting coins illegally, and this was regularly an item on the agenda of the parliament. This period is known as the era of aristocratic counterfeiting in the research. The most heavily archaeologically researched site of counterfeiting in these times operated at Csorbakő Castle next to Szuhogy. Here, in addition to unstruck silver-plated copper blanks, there were various copper clippings, blocks of raw materials, dross, crucibles and of course fake coins that were found (LESZIH 1941; SzÖRÉNYI 2003, 198-212).

The era of aristocratic counterfeiting was over by the 1550 s, however cases of counterfeiting continued, so there are lots of fake examples of later coins of Ferdinand I, as well as those of Maximilian I (1564-1576) and Rudolph I (1576-1608). Counterfeiting at the beginning of the 16th century can be connected to the peasantry in many cases (KAHLER 1975-1976, 54-55; GYÖNGYÖSSY 2019, 102). This was the same in the second half of the 16th century and in the 17th century as well, when forgers again

\footnotetext{
University of Szeged, Department of History. E-mail: vargamate12@gmail.com

Wosinsky Mór County Museum, Szekszárd. E-mail: knemetha@gmail.com
} 
Máté Varga-András K. Németh • Archaeological Traces of Rural Coin Counterfeiting in Tolna County

came from the lower classes, which is why this period is called the era of blacksmith counterfeiting. Tools and technology were primitive, so the images on the coins were of poorer quality, the silver content fluctuated, and the fakes were not typically made in large quantities, which is borne out in the majority of the finds presented below. This period ended in the 1630s (KÁPLÁR \& KAHLER 1976). Káplár and Kahler placed the era of blacksmith counterfeiting between 1560-1660 in an earlier paper (KÁPLÁR \& KAHLER 1973, 17).

\section{ARCHAEOLOGICAL SITES IN TOLNA COUNTY}

The first finds related to counterfeiting in Tolna County turned up in the 1980 s at the border of Bonyhádvarasd and Tevel. The previously known archaeological data were supplemented by Attila Gaál's field surveys, and he published the artefacts he found in a paper (GAÁL 2006). Then, due primarily to intensive research with metal detectors and the turning in of finds in the 2010s, new sites enriched our knowledge (in the order of discovery): Pincehely, Szakály (2 sites), Gyulaj, Jágónak, Zomba, Kisdorog, and Tolna. So far, material relics of counterfeiting are known from a total of ten sites in Tolna County (Fig. 1). This is a considerable number in terms of the data from the Carpathian Basin (VARGA \& NAGY 2017), since sites of this intensity from the same period can only be found in the Felvidék region (present-day: Slovakia). In 2015, there were 26 sites compiled by Máté Varga and Zsolt Nagy, but this number has risen to over 50 in recent years. These are sites with known evidence for counterfeiting of coins in the period. We know of a further 20 sites that are mentioned in written sources but have not yet produced archaeological evidence or such evidence is not known.

The research on the individual sites and the clarification and cataloguing of their finds is ongoing, and due to the quantity of finds, we can only currently publish preliminary results. It is possible to say in general that finds obviously related to illegal counterfeiting activities include round, unstruck copper blanks (rarely with slightly curving rims) and the copper sheets, the so-called clippings, the blanks were cut from (Fig. 2). Sometimes blanks were made from thin strips (Fig. 3), but these have only turned up in Tolna so far. These blanks may be silver-plated as well, but not in every case. We can conclude the blanks were plated with silver in certain cases after the coins were struck. Blanks turned up at every site, while clippings are known

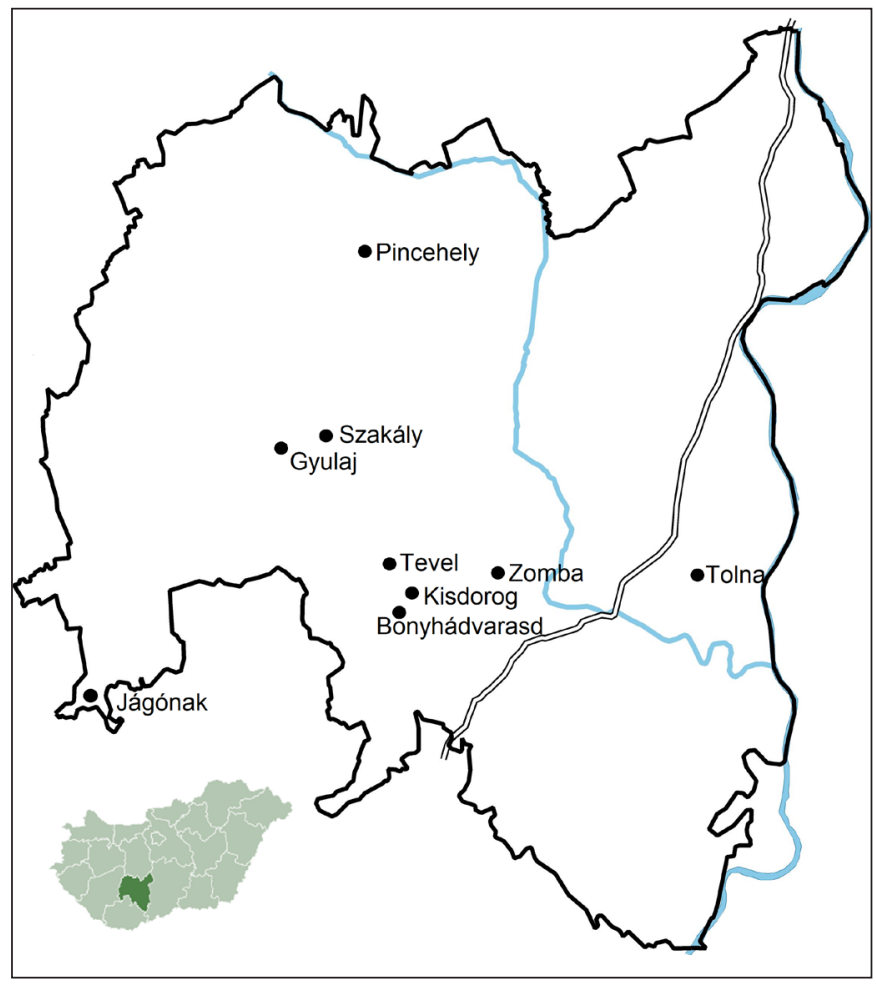

Fig. 1. Comprehensive map with the sites mentioned in the paper (Basic map: https://hu.wikipedia.org/wiki/Tolna megye; drawing: András K. Németh)

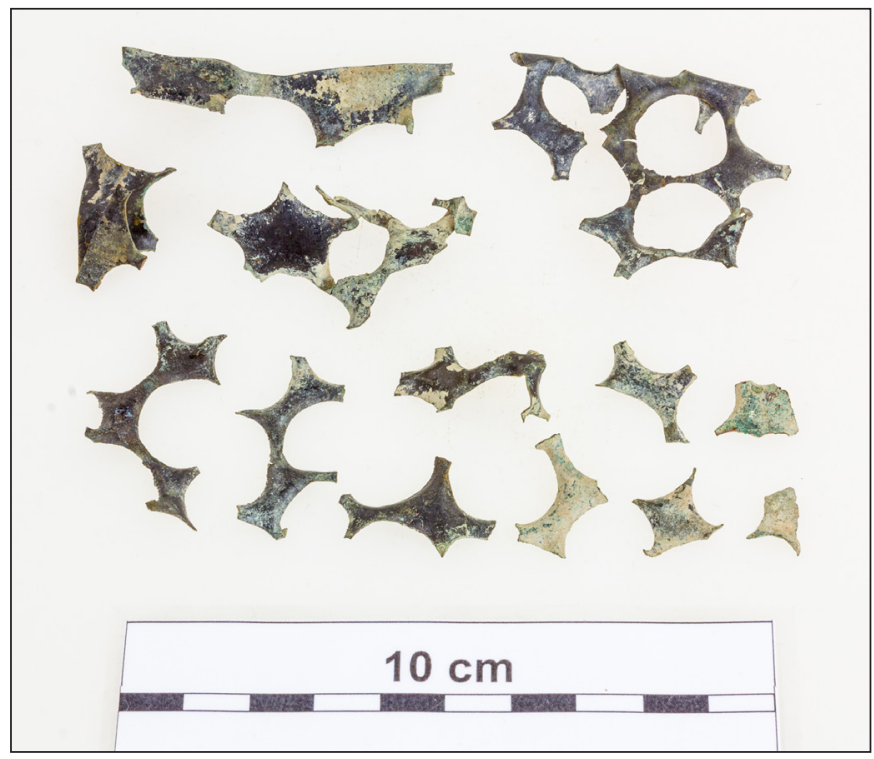

Fig. 2. Clippings of various shapes from Tolna (before cleaning) (Photograph: Tamás Retkes) 
Máté Varga-András K. Németh • Archaeological Traces of Rural Coin Counterfeiting in Tolna County

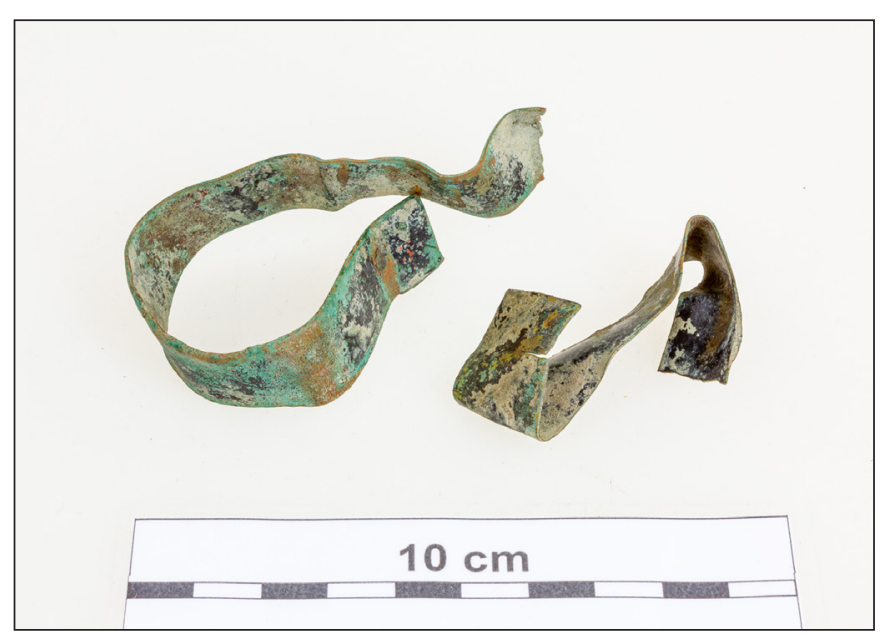

Fig. 3. Copper bands for making blanks from Tolna (before cleaning) (Photograph: Tamás Retkes)

from all the sites except for one (where we have not had the chance to collect finds yet, so we are limited to the finds that have been turned in). The greatest number of blanks have been found at the sites of Pincehely (nearly 100; VARGA 2016) and Tevel (40), The other sites have produced between 1 and 20 blanks each. Clippings have been found in greater amounts at the sites of Pincehely and Tolna, with almost 500 at Pincehely and more than 170 at Tolna (Fig. 4), while between 5 and 44 have been found at the other sites. At some sites, further copper sheets have turned up that due to their form must have been re-used, and can be considered raw materials for producing further blanks (Fig. $5)$. In addition, small nuggets of lead and tin were found at Tevel and Bonyhádvarasd (GAÁL 2006, $106,125)$ that may have been used for smelting and alloying. Major numbers of other features or finds (forges, slag, crucibles, tools) suggesting a workshop are not known from the sites at this time, but a few finds can still be mentioned. We have collected melted bronze, lead blanks and a metalsmith's hammer in Szakály, and a hammer head and bronze engraving tool (?) in addition to melted lead and bronze in Zomba. It should be noted here - leading to the issue of who the perpetrators were - a bronze press mould has been found in Zomba that was used to stamp metal sheets. The closest parallels to this are known from treasure troves from the Lower Danube region, which have been identified as Balkan-Turkish diadems or belts. The press mould indicates that other activities requiring similar skills may have been performed alongside counterfeiting at the site.

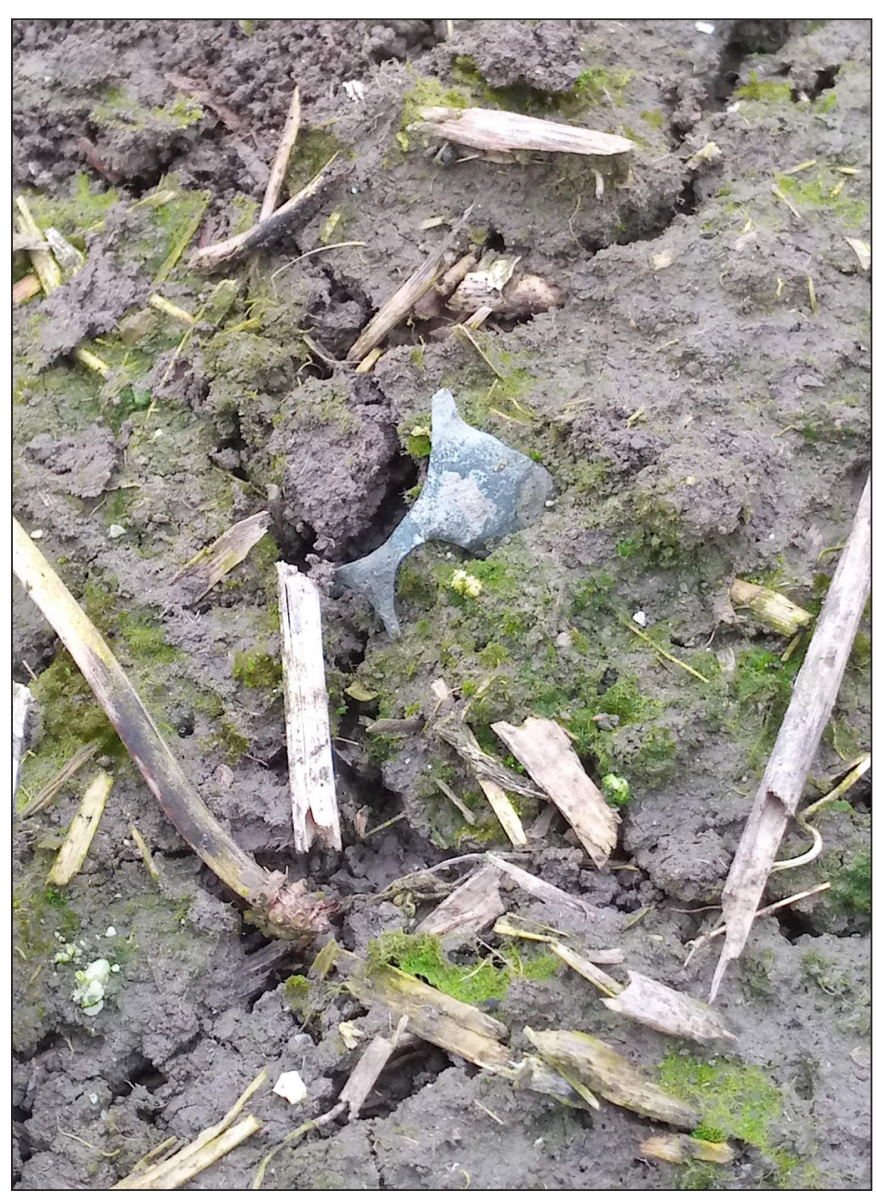

Fig. 4. Clipping from the field walk and surface recovery at Tolna (Photograph: András K. Németh)

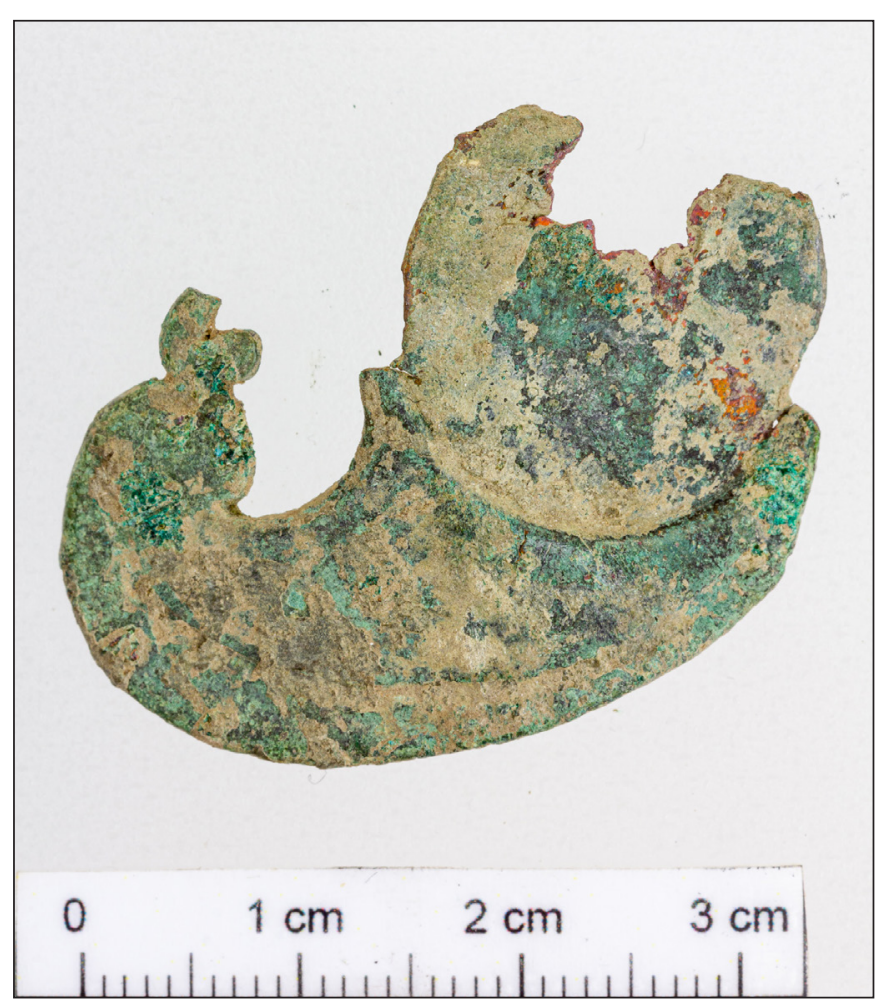

Fig. 5. Blank that was improperly cut and remained attached to the sheet used for the raw material from Kisdorog (before cleaning) (Photograph: Tamás Retkes) 
Máté Varga-András K. Németh • Archaeological Traces of Rural Coin Counterfeiting in Tolna County

\section{PARALLELS}

We do not know many Carpathian Basin sites similar in character to the Tolna County ones. The best parallels are the finds collected along the border of the Vámtelek Plain in Mala Bosna, Serbia. Here copper blanks (some that were plated in silver or lead), clippings, and counterfeit coins were found at four sites. These sites are within one kilometre of each other, three on one side of the Bács (Krivaja) Brook and one on the other side. There were 120 copper blanks (some silver plated) and almost 50 fake coins and clippings in the first assemblage; counterfeit dinars and clippings found in the second; exclusively forgeries of the coins of Rudolph I in the third; and silver coins, fake dinars, clippings, and round, partially silver-plated blanks in the fourth. The majority of the blanks are the size of dinars, but there were also those the size of groschens and half-thalers. These counterfeit coins may have been made in the 1570-80s (NAGY 2009-2010; NAGY 2011-2012).

Further data is known from two rural sites, both from Bács-Kiskun County that neighbours Tolna County. According to information from István Pánya, one copper blank and two clippings have been found in Kunpeszér. A fragment of a crucible and about ten copper blanks and fake coins have come to light from the area of the medieval village of Baracs in Kunbaracs (BuZÁs, KÖNIG \& PÁNYA 2019, 16-17). According to the hypothesis of the authors, the counterfeiting activities here might have taken place in the 1550s and they probably can be classified as aristocratic counterfeiting.

The unique character of the Tolna County sites is shown by the fact there has been intensive research with metal detectors combined with field walks in other nearby Transdanubian counties (Baranya, Fejér, Somogy), but similar finds have not been found yet.

\section{GEOGRAPHIC LOCATION AND EXTENT OF THE SITES}

Counterfeiting workshops are not spread uniformly throughout Tolna County. There is only one site on the plains, in Tolna, while the others are located in the hilly north-western and central sections of the county. The sites of the Outer Somogy Hills are in Jágónak and Pincehely next to the Kapos River, as well as one in Gyulaj and two in Szakály located close to the water on gentle slopes on either side of a tributary of the Kapos. The sites of Tevel, Zomba, Bonyhádvarasd and Kisdorog in the Tolna-Hegyhát and Völgység regions are located along small streams that flow into the Völgység Creek from the north, and are on the sides of narrow valleys except for the one in Zomba. Certain concentrations of counterfeiting sites can be recognized, which may suggest a possible chronological connection between them. This is particularly possible in the case of the workshops in Gyulaj and the two in Szakály, which are located within a radius of 500 meters, and only one is within a village while the others stood apart. The sites were concentrated in the Völgység and the Hegyhát regions as well. The sites of Tevel, Zomba and Kisdorog are ten, six and eight kilometres from one another, and the site of Bonyhádvarasd is in the middle of the triangle they form.

Only one of the ten workshops was in a castle (Jágónak), while the others were in village settlements or stood on their own. The settlements with counterfeiting workshops can be placed in two different groups, medieval villages and settlements established after the Ottoman conquest without medieval precedents. The workshop in Pincehely is from the Árpád Period, and the ones in Bonyhádvarasd, Pincehely and Tevel are in settlements from the Late Middle Ages that were also inhabited during the Ottoman Period. Half of the workshops (Gyulaj, Kisdorog, Szakály 1-2, Zomba) were identified on sites that were established in the mid-16th century at the earliest based on datable finds (primarily coins). At three of these five sites (Gyulaj, Szakály 2, Kisdorog), the workshop itself was the entire site, meaning that there was no evidence of a larger settlement around them. Therefore, according to our present knowledge, they stood alone, presumably deliberately separate and "hidden" from inhabited areas. Similar "temporary" counterfeiting workshops are known from written sources in other parts of the country. In the 1551 counterfeiting case of the aforementioned master metalworker Nicholas, peasants reported that they ran into Germans counterfeiting coins in the Csemernye Forest, who were striking the fake coins "on the stumps of hard trees" (KomÁromy 1893, 757-758). 
Máté Varga-András K. Németh • Archaeological Traces of Rural Coin Counterfeiting in Tolna County

Conclusions on the size of the workshops can be made in connection with surface finds (not including the counterfeit coins that were not necessarily made there). The areas demarcated by the blanks and clippings fall between two extremes, approximately $160 \times 90$ meters in Zomba and $100 \times 60$ meters in Tolna, only 40×20-30 meters in Gyulaj and Tevel, and only 20×10 meters in Bonyhádvarasd. It is possible to identify at least two workshop types from these data, larger ones that operated for a longer time and smaller ones - about the size of a house or building lot (?) - that operated from time to time or for a short period. Only in Zomba could we observe a smaller patch with brick and mortar debris within the area of counterfeiting finds, which may have been the former workshop building.

\section{DATING OF THE SITES IN TOLNA COUNTY AND THE POTENTIAL GROUP OF COUNTERFEITERS}

The dating of sites related to counterfeiting is not an easy task, because copper blanks and clippings on their own cannot be dated. Dating is made more difficult if it depends only on surface finds. Data on the diameters and weights of the blanks and clippings can help us too, as we can compare this information with the contemporaneous coins that were the basis of the forgeries or with the counterfeit coins found at the sites. The majority of the blanks found at the sites in Tolna County are the size of dinars (Fig. 6), with only a few cases of sizes larger than this.

In the case of sites that were used over several centuries, numerous coins and objects were found that did not make it easier to make a chronological determination for the counterfeiting activities. If there were fake coins from both the 16th and 17th centuries, which can be linked to the counterfeiting? However, at certain sites, there were only coins and other finds useful for dating from a given, briefer period or that were concentrated in a briefer period. For example, coins have turned up at the Pincehely site starting from the 12th-13th centuries all the way up to the 17th century. There are fake coins from the mints of Ferdinand I, Maximilian I, Rudolph I, and

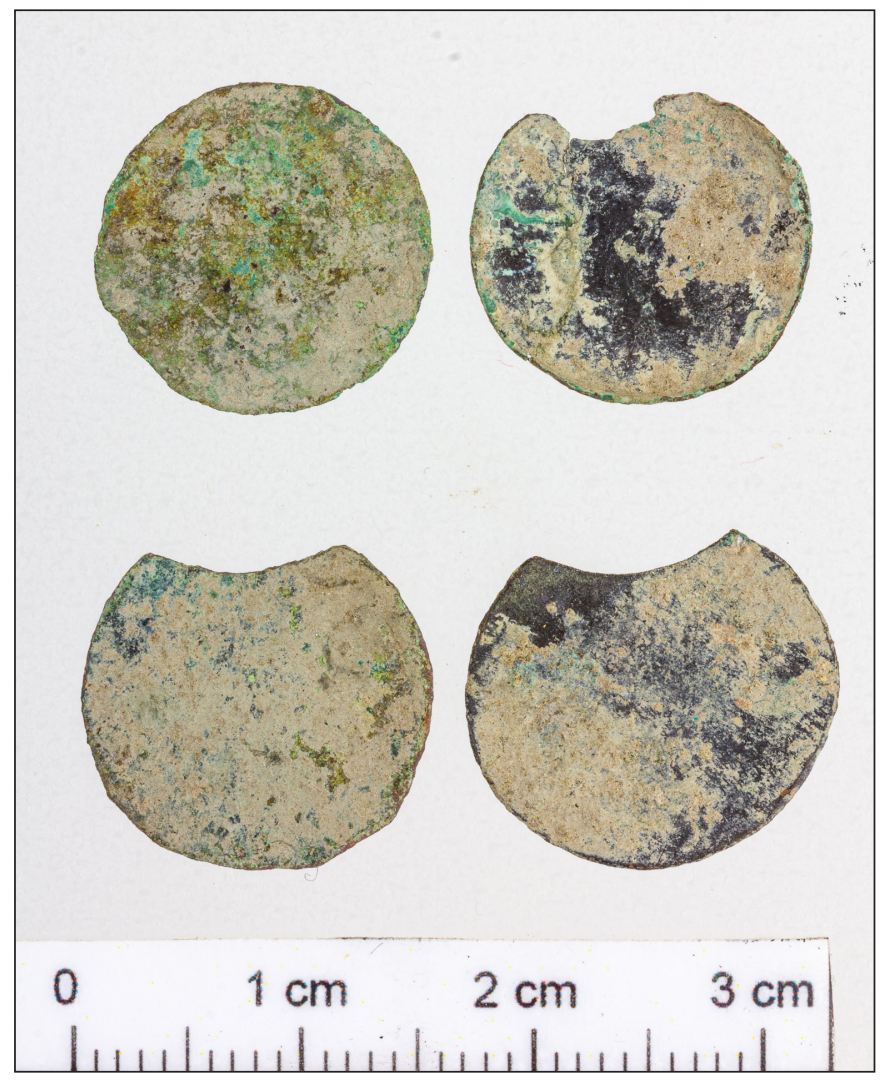

Fig. 6. Blanks the size of dinars from Tolna (before cleaning) (Photograph: Tamás Retkes) even Ferdinand II (1619-1637), so the counterfeiting here could theoretically be linked to the reign of any one of these rulers. However, the data on diameters and weights of the copper blanks suggest the time of Ferdinand II.

Based on this, we can date the sites of Kisdorog, Tevel and Bonyhádvarasd to the beginning of the 17th century and the Pincehely site to the first half of the 17th century. One of the Szakály sites and the one at Gyulaj can be dated to the end of the 16th and beginning of the 17th century (Figs. 7-8). The dating of the relatively few finds at Jágónak, Zomba, Tolna, and the other site at Szakály are still uncertain, although the Szakály site was probably used at the end of the 16th or at the beginning of the 17th century, because the two sites at Szakály and the one at Zomba are very near to one another. According to the formal indications of the blanks and clippings at the sites of Jágónak, Zomba and Tolna, the counterfeiting may have taken place in the 16th-17th centuries.

Here, we will just briefly suggest the possible users and creators of the aforementioned 17th century counterfeiting workshops (primarily Pincehely and Zomba, as well as Bonyhádvarasd, Tevel, and the work- 
Máté Varga-András K. Németh • Archaeological Traces of Rural Coin Counterfeiting in Tolna County

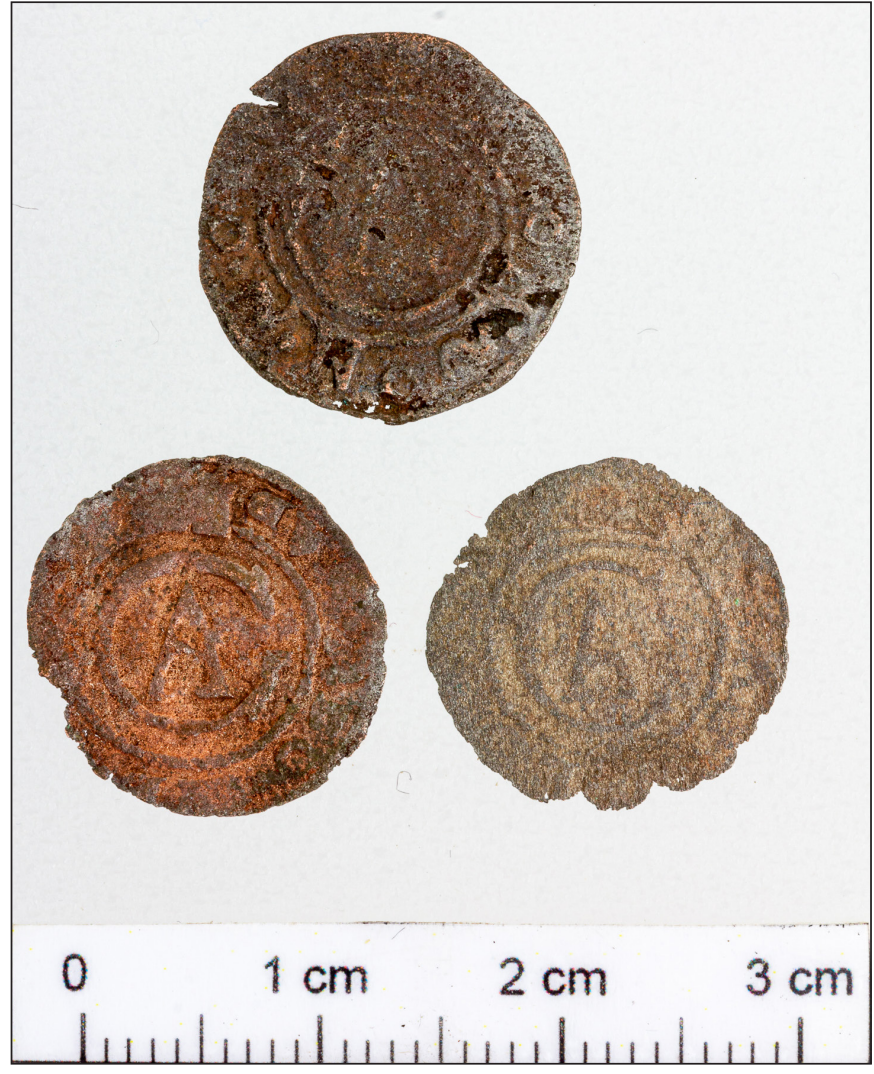

Fig. 7. Counterfeit coins with the name of the Swedish King Gustavus Adolphus II (1611-1632) from Kisdorog (before cleaning) (Photograph: Tamás Retkes)

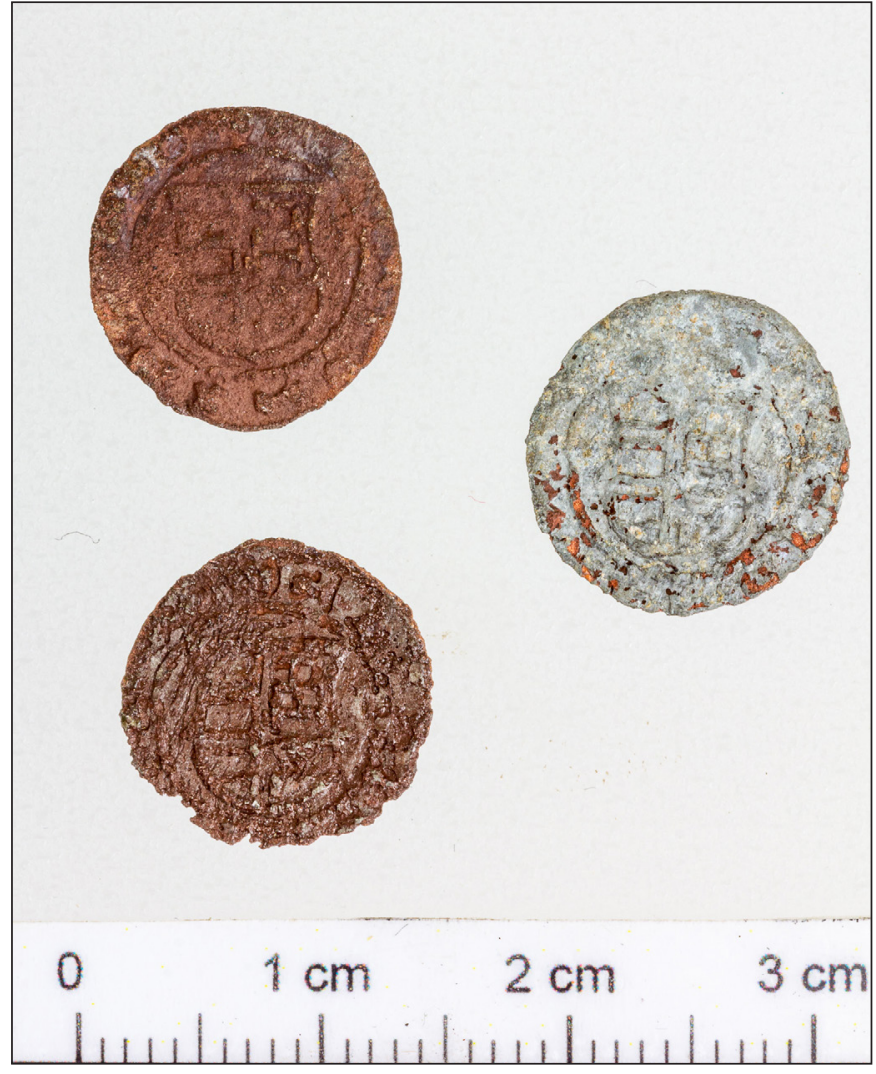

Fig. 8. Fake dinars from the beginning of the 17th century from Gyulaj (restored condition) (Photograph: Tamás Retkes)

shop-complex in Gyulaj-Szakály). It should not be ignored that a significant portion of the inhabitants in Tolna County were from the Balkan - primarily Southern Slavic - minority, the so-called "rác" (Serbian) people. In the decades after the Long Turkish War (1591-1606), they often did not take up residence in the destroyed medieval Hungarian villages, but created new, independent settlements next to them. Here it is not possible to elaborate the increasing archaeological traces and evidence of this, but the suspicion is strong that this population can be linked to certain evidence of counterfeiting identified at Ottoman Period settlements without medieval roots, just as the press mould mentioned in connection with the Zomba workshop indicates.

\section{ACKNOWLEDGEMENTS}

The Tolna site was identified by the archaeologist Gábor K. Tóth, Kisdorog by the amateur metal detector András Fazekas in cooperation with the museum, and Szakály and Gyulaj by a collector who requested anonymity. In addition to the above, we would like to thank the archaeologist Attila Czövek; amateur metal detectors cooperating with the museum László Bulla, Attila Jókai, Miklós Kántor, Attila Korossy, Péter Mészáros, Lajos Sándor, Péter Vincze, and Krisztián Wagner; restoration experts Gábor Tamás Künsztler, András Tövisháti and Vince Ács; and photographer Tamás Retkes for their work and assistance.

\section{RECOMMENDED LITERATURE}

Bohdaneczky, I. (1935-1936). A pénzhamisítás Magyarországon a középkorban [Coin-counterfeiting in the Middle Ages in Hungary]. Numizmatikai Közlöny 34-35, 48-58. 
Máté Varga-András K. Németh • Archaeological Traces of Rural Coin Counterfeiting in Tolna County

Huszár, L. (1969). Magyar várak, mint pénzhamisító mühelyek a XVI. században [Hungarian fortresses as counterfeiter workshops in the 16th century]. Müemlékvédelem 13 (2), 80-87.

Komáromy, A. (1893). Egy hamis pénzverő a XVI. században [A counterfeiter in the 16th century]. Századok $27(8), 647-667$.

Komáromy, A. (1893). Egy hamis pénzverő a XVI. században. Második és befejező közlemény [A coincounterfeiter in the 16th century. Ending publication]. Századok 27 (9), 748-759.

Varga, M. \& Nagy, Zs. D. (2017). Coin Counterfeiter Workshops in Hungary during Medieval and Early Modern Ages. In B. Zajac et al. (eds.), Pecunia Omnes Vincit. The Coins as an Evidence of Propaganda, Reorganization and Forgery. Conference proceedings of the 2nd international numismatic conference, Krakow, 29-30 May 2015. (pp. 123-143). Kraków: Institute of Archaeology, Jagiellonian University.

\section{BIBLIOGRAPHY}

Buzás, G., Kőnig, F. \& Pánya, I. (2019). Középkori templomok nyomában Bács-Kiskun megyében I. [In the trace of medieval churches in Bács-Kiskun county]. Várak, kastélyok, templomok 15 (2), 14-17.

Gaál, A. (2006). Falusi pénzhamisító mühelyek emlékanyaga a Tolna megyei Tevel és Bonyhádvarasd határából (Gedenkmaterial der ländlichen Geldfälscherwerkstätte aus der Mark der Gemeinden Tevel und Bonyhádvarasd im Komitat Tolnau). A Wosinsky Mór Múzeum Évkönyve 28, 105-132.

Gyöngyössy, M. (2019). Pankart és csopce. Pénzverés és pénzforgalom Nyugat-Magyarországon (13871608) [Pankart and csopce. Coinage and cash flow in Western-Hungary (1387-1608)] Mosonmagyaróvár: Hansági Múzeum.

Kahler, F. (1975-1976). A XVI. századi pénzhamisítás kérdéséhez (Zur Frage der Falschmünzerei im XVI. Jahrhundert). Numizmatikai Közlöny 74-75, 53-56.

Kahler, F. (1977-1978). A magyarországi középkori pénzhamisítás (I. rész) (Mittelalterliche Falschgeldprägung in Ungarn). Numizmatikai Közlöny 76-77, 57-65.

Kahler, F. (1981-1982). Középkori pénzhamisításunk kérdéséhez (III. befejező rész) (Die mittelalterliche Geldfälschung in Ungarn (abschließender Teil). Numizmatikai Közlöny 80-81, 79-83.

Káplár, L. \& Kahler, F. (1973). Adatok a XVI. századi pénzhamisítás kérdéséhez [Data to the question of the medieval coin-counterfeiting]. Az Érem 29 (1), 17-21.

Káplár, L. \& Kahler, F. (1976). Adatok a magyarországi pénzhamisítás kérdéseihez; a pénzhamisítás technikájának alakulása az újkorban (Angaben zur Frage der Falschmünzerei in Ungarn. Die Gestaltung der Technik der Falschmünzerei in der Neuzeit). Déri Múzeum Évkönyve 1976 [1977], 137-149.

Komáromy, A. (1893). Egy hamis pénzverő a XVI. században [A counterfeiter in the 16th century]. Századok 27 (8), 647-667.

Komáromy, A. (1893). Egy hamis pénzverő a XVI. században. Második és befejező közlemény [A counterfeiter in the 16th century. Second end ending publication]. Századok 27 (9), 748-759. 
Máté Varga-András K. Németh • Archaeological Traces of Rural Coin Counterfeiting in Tolna County

Leszih, A. (1941). A szuhogyi csorbakői vár XVI. századbeli pénzhamisító mühelye [Counterfeiting workshop from the 16th century in the Csorbakő castle in Szuhogy]. Numizmatikai Közlöny 40, 49-54.

Nagy, J. (2009-2010). Két XVI. századi hamis éremlelet Vámtelekről (Zwei Falschmünzfunde aus dem 16. Jahrhundert in Vámtelek). Numizmatikai Közlöny 108-109, 215-222.

Nagy, J. (2011-2012). Újabb két XVI. századi hamis éremlelet Vámtelekről (Zwei neue Falschmünzfunde aus dem 16. Jahrhundert in Vámtelek). Numizmatikai Közlöny 110-111, 139-144.

Szörényi, G. A. (2003). A csorbakői vár története 1648-ig (The history of the castle of Csorbakő until 1648). A Herman Ottó Múzeum Évkönyve 42, 165-226.

Varga, M. (2016). 17. századi pénzhamisító műhely leletei Pincehely határából (Fundobjekte einer Geldfälscherwerkstatt aus dem 17. Jahrhundert am Flur von Pincehely). A Wosinsky Mór Múzeum Évkönyve 38, 329-348.

Varga, M. \& Nagy, Zs. D. (2017). Coin Counterfeiter Workshops in Hungary during Medieval and Early Modern Ages. In B. Zajac et al. (eds.), Pecunia Omnes Vincit. The Coins as an Evidence of Propaganda, Reorganization and Forgery. Conference proceedings of the 2nd international numismatic conference, Krakow, 29-30 May 2015. (pp. 123-143). Kraków: Institute of Archaeology, Jagiellonian University. 